\title{
Electrochemical Characteristics of Particulate Matter
}

\author{
Margarita Baitimirova $^{1}$, Agnese Osite ${ }^{2}$, \\ Juris Katkevich ${ }^{3}$, Arturs Viksna ${ }^{4},{ }^{1-4}$ University of Latvia
}

\begin{abstract}
The current work is dedicated to electrochemical impedance spectra analysis of the fine and coarse airborne particulate matter sampled on the glass fibre filters in Riga city air. The cyclic voltammograms, impedance spectra and double layer capacitance spectra of particulate matter were obtained after the pre-treatment of samples. The equivalent circuit method and the statistical method were used for impedance spectra analysis. Analyzing the impedance spectra, it was concluded that the impedance of both - fine and coarse particles heated in $\mathbf{N}_{2}$ flow does not change by aerosol mass concentration variations. On the other hand, the impedance of particulate matter heated in $\mathrm{O}_{2}$ flow increases, by increasing $\mathbf{P M}_{10}$ mass concentration. Describing the spectra of double layer capacitance, it was observed that the double layer capacitance of aerosols heated in $\mathrm{N}_{2}$ flow did not change, by mass concentration and size variations. However, by increasing mass concentration of coarse aerosols heated in $\mathrm{O}_{2}$ flow, the double layer capacitance reduced.
\end{abstract}

Keywords - Particulate matter, impedance spectra, equivalent electrical circuit, double layer capacitance

\section{INTRODUCTION}

In the last years, with the increase of harmful gases and particulate matter quantities in the atmosphere, the supervision and research of suspended particulate matter (aerosol) is of a global importance. Particulate matter is an aerosol, which is formed in the atmosphere in the form of various size particles and/or drops. Airborne aerosols are coarse $(2.5-10 \mu \mathrm{m}$ in diameter) and fine $(\leq 2.5 \mu \mathrm{m})$. The coarse particulate matter has designate $\mathrm{PM}_{10}$, but the fine - $\mathrm{PM}_{2.5}$. Fine airborne particulate matter, remaining in the atmosphere for a long time and evenly expanding in the city air (from some days to some weeks), has harmful impact on people's health. $\mathrm{PM}_{10}$ particles may be detained in the top of respiratory ways, may harden, and thus become a source of irritation. In turn, the $\mathrm{PM}_{25}$ particles may reach the blood or even the lymphatic system from the lung's alveolus which can cause cardiovascular and other serious illnesses. Microorganisms, bacteria or fungi, as components of particulate matter, can cause allergies [1].

Airborne particulate matter causes not only danger to health, but also has an effect on the solar radiation balance of the Earth. Particles of black carbon are most effective in absorbing solar and infrared radiation, which causes atmosphere warming [2]. Recent studies suggest that black carbon is the second strongest contributor to the current global warming, after carbon dioxide emissions [3]. All the same fine particles of black carbon have an inverse effect: they scatter radiation, thus making the planet's surface cold [4]. Fine particles serve as condensation nucleus of clouds; they form drops of fog or clouds in a saturated water vapour [5]. The fine drops of clouds increase aerosols' total surface of water, thus scales up the scattering of clouds and their staying in the atmosphere, which creates additional cooling of the Earth's surface [4].

The components of airborne particular matter depend on their source of origin. The soil erosion and the mineral aeration are source of $\mathrm{Al}, \mathrm{Fe}, \mathrm{Ca}, \mathrm{Si}$ elements in airborne particle's composition. Fossil fuel incomplete combustion is source of $\mathrm{C}$ in particulate matter, while sea, ocean aerosols and fossil fuel combustion are source of $\mathrm{Na}^{+}, \mathrm{Cl}^{-}, \mathrm{SO}_{4}{ }^{2-}$ ions. Fuel and garbage combustion are source of $\mathrm{Pb}$ in aerosol particles' composition. Components of natural origin particulate matter are $\mathrm{K}, \mathrm{Al}, \mathrm{Si}, \mathrm{Na}, \mathrm{I}, \mathrm{Fe}, \mathrm{Cl}$ un $\mathrm{C}$ compounds. The ambient particulate matter also includes heavy metallic elements and complicated organic compounds resulting from human activities. For example, complex organic compounds on the aerosol surface originated from incomplete combustion of different products and thermo synthesis process. Such aerosols include many groups of organic compounds: aliphatic and aromatic hydrocarbons, aldehydes, ketones, carboxylic acids, heterocyclic and chlororganic compounds. Energy, heating, transport, industry and agriculture are the main sources of anthropogenic particular matter in Latvia.

Most aerosol particles have some electrical charge and may be highly charged in some circumstances. When charged particles are subject to an electrostatic field, they experience a force that gives rise to particle motion [6]. It allows analyzing particulate matter by the electrochemical impedance spectroscopy. The impedance spectroscopy is an electrical method, which allows researching some physical, physicochemical, electrochemical system properties observing their response to weak external influence. The electrochemical impedance is a complex resistance of an electric system, which is measured to bring the alternating current voltage to an electrochemical cell and to measure the through flowing electric current. Usually, the potential is very small $(\sim 5 \mathrm{mV})$, and it works as an excitation signal [7]. The electrochemical impedance spectra analysis of airborne particulate matter can give complicated information about electrostatic and electrodynamic properties of particulate matter. In the future, the impedance spectroscopy could be used for the quantitative determination of particulate matter.

In previous research, the impedance spectra of black carbon were investigated as one of the most important component of airborne particles [8]. It was determined that the impedance depends on the mass of black carbon and the mass of other carbonaceous components, which were not black, as well on filter pore packing with solid particles. The fine and coarse fractions of the particulate matter, however, have not been investigated. Therefore, the purpose of the particular research 
was to perform impedance measurements of the fractions of fine and coarse particulate matter.

\section{EXPERIMENTAL}

\section{A. Airborne Particular Matter Samples}

The current work is dedicated to the electrochemical impedance spectra analysis of fine and coarse airborne particulate matter sampled on the glass fibre filters in the air of the city of Riga. Airborne particulate matter was sampled by the dichotomous impactor, which fractionated aerosol particles by size: coarse $\left(2.5-10 \mu \mathrm{m}\right.$, which designate $\left.\mathrm{PM}_{10}\right)$ and fine $\left(\leq 2.5 \mu \mathrm{m}\right.$, which designate $\left.\mathrm{PM}_{2.5}\right)$. The dichotomous impactor was placed in Riga, on Kr. Valdemara 48 ( $~ 8 \mathrm{~m}$ above ground level and $\sim 1 \mathrm{~m}$ from building wall). The 24, 72 and 96 hours sampling duration was chosen for various mass concentrations of aerosol particles. The sampling air flow rate was fixed about $1 \mathrm{~m}^{3} / \mathrm{h}$. Particulate matter was sampled in October, 2010. The weather during this period was cloudy, at times rainy and cleared up at other times. Air temperatures were $+5 \ldots+9{ }^{\circ} \mathrm{C}$. Wind blew from the south, south-east, with the 4-9 $\mathrm{m} / \mathrm{s}$ speed. Mass concentrations of particulate matter $(\gamma)$ and the corresponding volumes of sampled air $(\mathrm{V})$ are presented in Table 1. Samples of particular matter were numbered by a sequence of mass concentration increase (the first had the lower mass concentration of aerosols, the second - medium and the third - the largest).

TABLE 1

MASS CONCENTRATIONS OF PARTICULATE MATTER $(\gamma)$ AND THE CORRESPONDING VOLUMES OF SAMPLED AIR (V)

\begin{tabular}{|l|l|l|}
\hline Sample & $\mathbf{V}, \mathbf{m}^{\mathbf{3}}$ & $\gamma \pm \mathbf{S}_{\mathbf{3}}, \boldsymbol{\mu g} / \mathbf{m}^{\mathbf{3}}$ \\
\hline PM2.5-1 & 24.04 & $5.0 \pm 0.2$ \\
\hline PM2.5-2 & 72.85 & $11.70 \pm 0.07$ \\
\hline PM2.5-3 & 96.77 & $24.0 \pm 0.2$ \\
\hline PM10-1 & 24.04 & $3.24 \pm 0.05$ \\
\hline PM10-2 & 72.85 & $6.0 \pm 0.2$ \\
\hline PM10-3 & 96.77 & $10.61 \pm 0.05$ \\
\hline
\end{tabular}

\section{B. Particulate Matter Heating and Carbonisation}

In the previous research [8], it was noticed that samples with a rather high mass concentration of particulate matter have bad wetting in electrolyte. This fact has a negative impact to the impedance measurements. Firstly, impedance measurement of the bad wetting sample gave an erroneous representation about the system. Secondly, the sample damage occurred, when air vials are penetrating between the electrode and the analyzed sample, as a result of the sample's bad wetting in electrolyte. Therefore, samples of particulate matter were cut into two parts (as shown in Figure 1). One part was heated for $60 \mathrm{~min}$ at $410^{\circ} \mathrm{C}$ in a nitrogen $\left(\mathrm{N}_{2}\right)$ flow, the other part - for $60 \mathrm{~min}$ at $510^{\circ} \mathrm{C}$ in an oxygen $\left(\mathrm{O}_{2}\right)$ flow to increase the samples' wetting in electrolyte. When particulate matter was carbonised in $\mathrm{N}_{2}$ flow, organic compounds collapsed to elemental carbon (the main component of airborne particulate matter). When samples of particulate matter were heated in $\mathrm{O}_{2}$ flow, organic compounds completely collapsed to water and carbon dioxide. The alteration of a particulate matter sample, depending on the kind of treatment (after carbonisation in the $\mathrm{N}_{2}$ flow and after heating in the $\mathrm{O}_{2}$ flow), is shown in Figure 2.

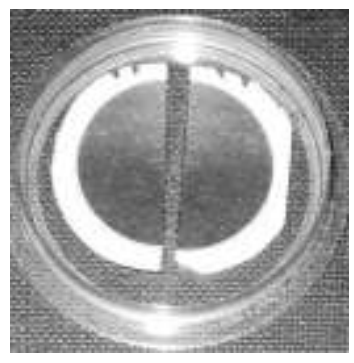

Fig. 1. Sample of particulate matter before treatment.

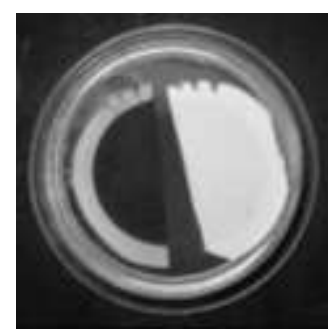

Fig. 2. Sample of particulate matter after treatment (at the left - after carbonisation in $\mathrm{N}_{2}$ flow, at the right - after heating in $\mathrm{O}_{2}$ flow).

\section{Cyclic Voltammogram Obtaining}

A "sandwich" type electrochemical cell was prepared for impedance measurements (Fig. 3). $0.1 \mathrm{M} \mathrm{K}_{2} \mathrm{SO}_{4}$ aqueous solution was used as the electrolyte. The Pt electrode $(1 \times 1 \mathrm{~cm})$ was used as the cathode, the Pt electrode $(2.5 \times 2.5 \mathrm{~cm})$ - as the anode, and the $\mathrm{Ag} / \mathrm{AgCl}$ spiral electrode was used as the reference electrode. The sample of particulate matter was placed between the surfaces of the cathode and the anode with a layer of absorbed aerosols upward.

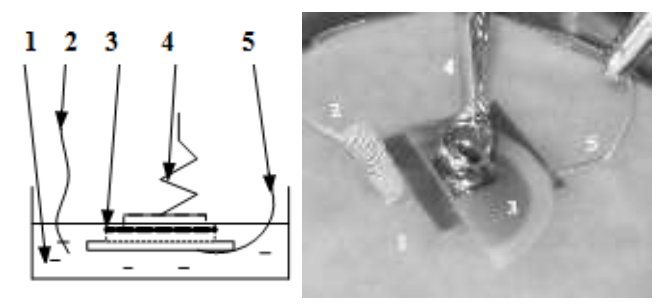

Fig. 3. "Sandwich" type electrochemical cell for impedance measurements $(1$ - the Petri dish with electrolyte, 2 - the reference electrode, 3 - the analyzing sample, 4 - the cathode, 5 - the anode).

Impedance measurements can be obtained by using the potential in the statistic and the kinetic areas. A charge is formed in the statistic area, but the movement of charged ions begins in the kinetic area. Cyclic voltammograms of particular matter were obtained for potentials determination in statistic and kinetic areas (Fig. 4). The cyclic voltammogram is a dependence between the current strength (I) and potential (E). In contradistinction to the linear-sweep voltammetry, the cyclic voltammetry potential is scanned not only from begin to end potential, but also from end to begin potential [9]. The computer program General Purpose Electrochemical System 
$(G P E S)$ was used for obtaining the cyclic voltammrogram. The cyclogram was obtained by scanning potential from -0.4 $\mathrm{V}$ to $+1.3 \mathrm{~V}$.

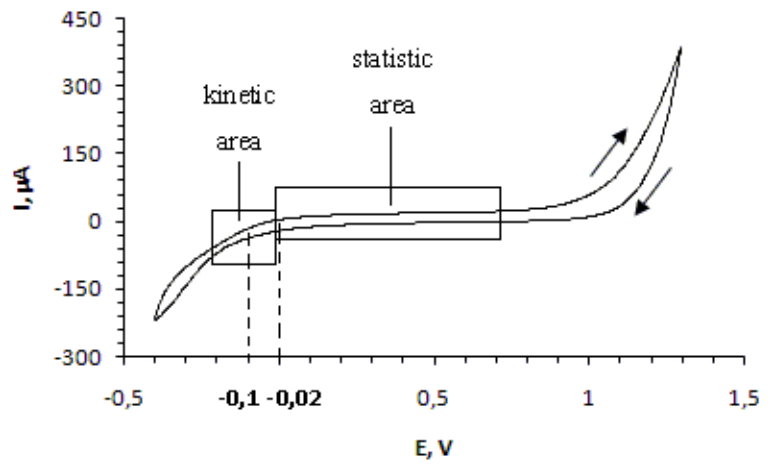

Fig. 4. Cyclic voltammogram of particulate matter.

The equilibrium potential of particulate matter was determined by using the obtained electrochemical window (Fig. 4). The equilibrium potential was from $-0.05 \mathrm{~V}$ to +0.7 $\mathrm{V}$. The potential $-0.02 \mathrm{~V}$ corresponded to the statistic area and the potential $-0.1 \mathrm{~V}-$ the kinetic area. Both potentials were used for next impedance measurements, in order to describe the complex resistance of airborne particular matter in statistic and kinetic areas.

\section{Electrochemical Impedance Spectra Measurements}

Impedance measurements of particulate matter were obtained at the potential in the statistic area and at the potential in the kinetic area. Experimental parameters were regulated by the computer program Frequency Response Analyser (FRA). At first, impedance measurements were obtained at potential, which was in the statistic area $(-0.02 \mathrm{~V})$, then - at potential, which was in the kinetic area $(-0.1 \mathrm{~V})$. Potential frequencies were from $10 \mathrm{kHz}$ to $0.1 \mathrm{~Hz}$. Number of frequencies -40 . The potential amplitude of measurements was $0.010 \mathrm{~V}$. The impedance spectra of each sample of particulate matter were obtained after $15 \mathrm{~min}$ from the beginning of the conditioning. For the illustration, the untreated impedance spectrum of aerosol particles is shown in Figure 5.

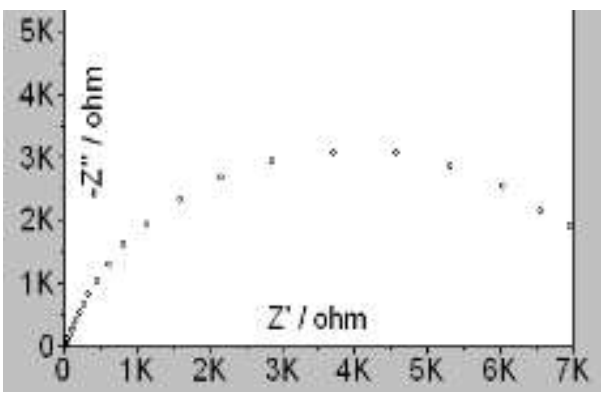

Fig. 5. Impedance spectrum of particulate matter.

Measurement accuracy and certainty were checked by the Kramers-Kroning test [10]: chi-square should be smaller $10^{-4}$. If this value is larger than $10^{-4}$, the obtained data can not be used further. When chi-square value is equal $10^{-4}$, the obtained data includes rough errors. These spectra must be improved, if some separated not subordinated points in the lower and higher frequency areas are deleted. These points are not used for the next data processing.

\section{E. Double Layer Capacitance Spectra Measurements}

The spectra of double layer capacitance define a double layer between the composite electrode and electrolyte. Double layer capacitance spectra of particulate matter were obtained by potential scanning from $-0.3 \mathrm{~V}$ to $+0.3 \mathrm{~V}$ at the initial frequency $1.0 \mathrm{~Hz}$ and the final frequency $0.9 \mathrm{~Hz}$, the amplitude $-0.01 \mathrm{~V}$. For the illustration, the double layer capacitance spectrum of the untreated particulate matter is shown in Figure 6.

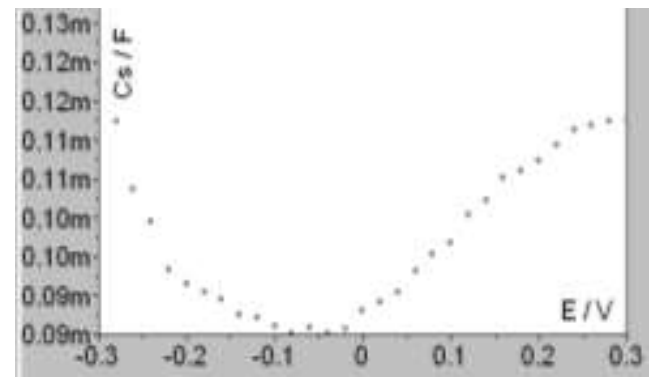

Fig. 6. Double layer capacitance spectrum of particulate matter.

\section{RESULTS AND DISCUSSION}

\section{A. Impedance Spectra Analysis}

The impedance spectra of particulate matter were calculated in the common scale (Fig. 7). The impedance spectra in the common scale were almost identical, the impedance modulus of samples with various aerosol particles' size, mass concentrations and pre-treatment were of the same kind. It means that the spectra were homogeneous and the comparison among themselves was correct [11].

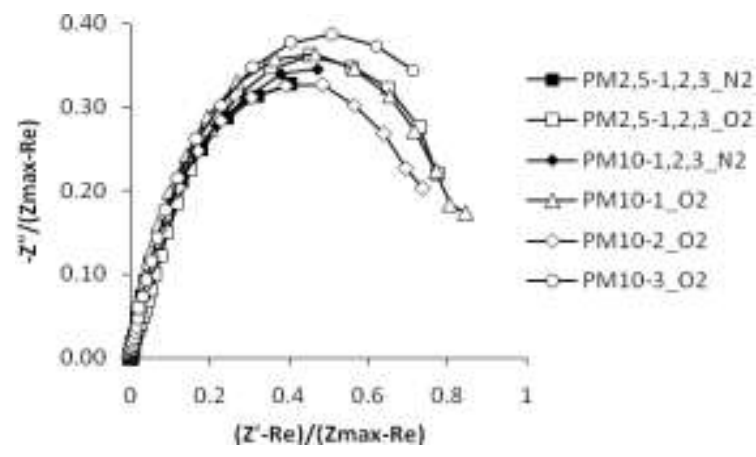

Fig. 7. Impedance spectra of $\mathrm{PM} 2.5$ and $\mathrm{PM}_{10}$ aerosols in common scale.

The impedance spectra of particulate matter obtained at the potential $-0.02 \mathrm{~V}$ are shown in Figure 8, and at the potential $0.1 \mathrm{~V}-$ in Figure 9. 


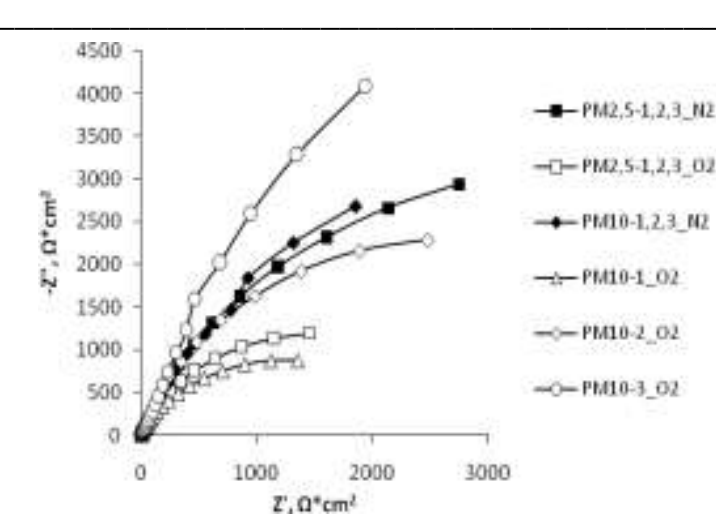

Fig. 8. Impedance spectra of $\mathrm{PM}_{2.5}$ and $\mathrm{PM}_{10}$ aerosols at potential $-0.02 \mathrm{~V}\left(\mathrm{~N}_{2}\right.$ - heated in nitrogen flow, $\mathrm{O}_{2}$ - heated in oxygen flow).

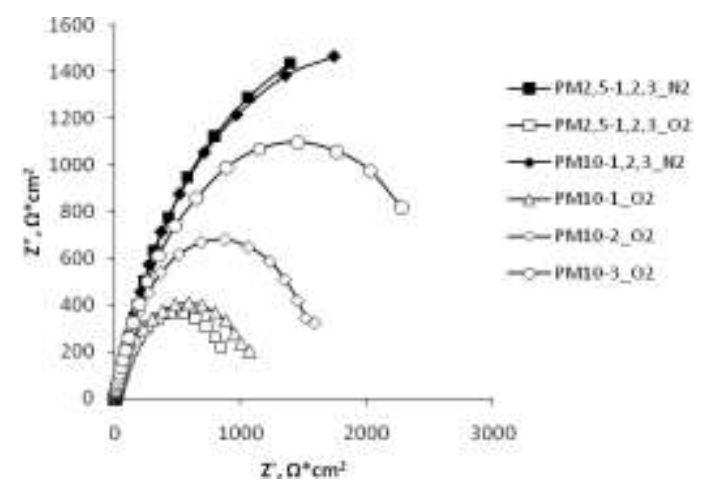

Fig. 9. Impedance spectra of $\mathrm{PM}_{2.5}$ and $\mathrm{PM}_{10}$ aerosols at potential $-0.1 \mathrm{~V}\left(\mathrm{~N}_{2}-\right.$ heated in nitrogen flow, $\mathrm{O}_{2}$ - heated in oxygen flow).

The impedance spectra of particulate matter heated in $\mathrm{N}_{2}$ flow almost did not change by mass concentration and size variations, as shown in Figures 8 and 9. The impedance of particulate matter heated in $\mathrm{O}_{2}$ flow did not change by mass concentration of fine particles $\left(\mathrm{PM}_{2.5}\right)$ variation, but it increased by increasing mass concentration of coarse particles $\left(\mathrm{PM}_{10}\right)$.

The equivalent circuit method was used for the impedance spectra analysis in order to describe the process on the electrode and to get electrochemical characteristics of particulate matter. The equivalent circuit method is based on the equivalent circuit fitting to analyzing system. Usually equivalent circuit elements are resistors, capacitors and "nonideal capacitors", or constant phase elements. Both serial and parallel combinations of element occur. The equivalent circuit method is an accurate method; it gives more extra information about analyzing system, and that is why it is used often.

The FRA computer program was used for fitting equivalent circuit to impedance spectra. The equivalent circuit of impedance spectra of $\mathrm{PM}_{2.5}$ and $\mathrm{PM}_{10}$ aerosols heated in $\mathrm{O}_{2}$ flow is shown in Figure 10, A. In turn, the equivalent circuit of impedance spectra of $\mathrm{PM}_{2.5}$ and $\mathrm{PM}_{10}$ aerosols heated in $\mathrm{N}_{2}$ flow is shown in Figure 10, B. The resistor $R_{l}$ describes the electrolyte solution resistance, the constant phase element $Q_{l}$ and the capacitor $C_{1}$ - the electrical double layer capacitance, the resistors $R_{2}$ and $R_{3}-$ the polarization resistance of electrode.
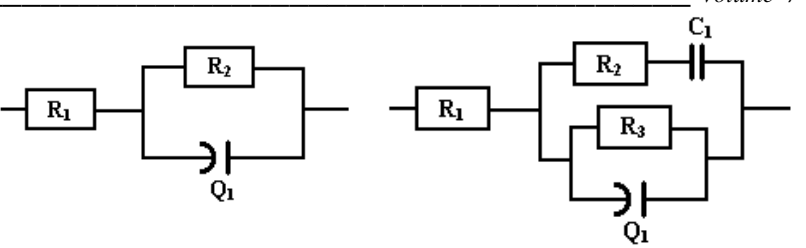

A

Fig. 10. The equivalent circuit of $\mathrm{PM}_{2.5}$ and $\mathrm{PM}_{10}$ aerosols: $\mathrm{A}$ - heated in $\mathrm{O}_{2}$ flow, B - heated in $\mathrm{N}_{2}$ flow.

Equivalent circuits by the real system are shown in Figure 11 (the "sandwich" type electrochemical cell, the glass fibre filter with particulate matter, the electrolyte).

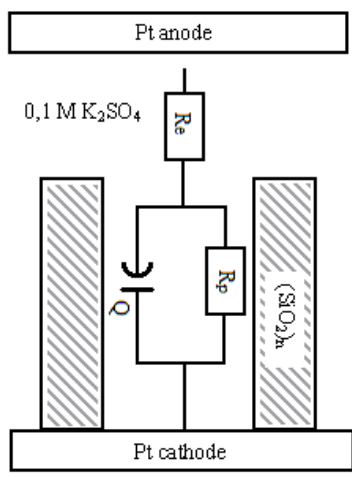

A

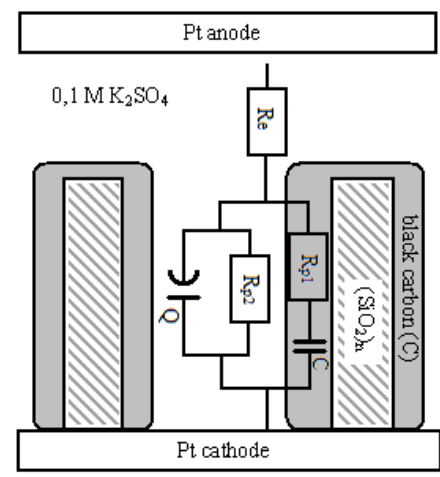

Fig. 11. The equivalent circuits of $\mathrm{PM}_{2.5}$ and $\mathrm{PM}_{10}$ aerosols by the real system: $\mathrm{A}$ - heated in $\mathrm{O}_{2}$ flow, $\mathrm{B}$ - heated in $\mathrm{N}_{2}$ flow.

In both cases, the resistance $R_{e}$ is describing the electrolyte resistance. The resistance $R_{p}$ and the constant phase element $Q$ in parallel series described capillary in glass fibre filter. The resistance $R_{p 1}$ and the capacitor $C$ series were additionally joined parallel to Randles cell in equivalent circuit of particulate matter heated in $\mathrm{N}_{2}$ flow (Fig. 11, B), which is describing the carbon layer appeared in $\mathrm{N}_{2}$ flow.

The constant phase element $Q$ (with phase-shift coefficient $n$ 0.7-0.8) in both equivalent circuits showed the system's heterogeneity. This was explained by the coarse surface of the platinum electrode and the glass fibre filter's fibrous structure, without certain pores size. Describing the impedance spectra in high frequencies' area was confirmed by not cylindrical forms of filter's glass fibres [12]. The straight line with a slope of more then $45^{\circ}$, instead of a line with the slope equal to $45^{\circ}$, corresponded to the rhomboid or triangular fibres, which are touching each other with narrow end (Fig. 12).
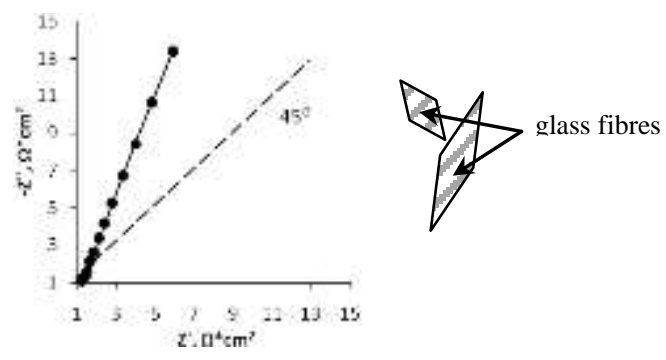

Fig. 12. The impedance spectrum of particulate matter in high frequencies' area and glass fibre filter's structure. 
No cylindrical forms of a filter's glass fibres might be the reason for the difference between equivalent circuits of particulate matter heated in the $\mathrm{N}_{2}$ flow and the equivalent circuit of porous material mentioned in literature (Fig. 13) [11].

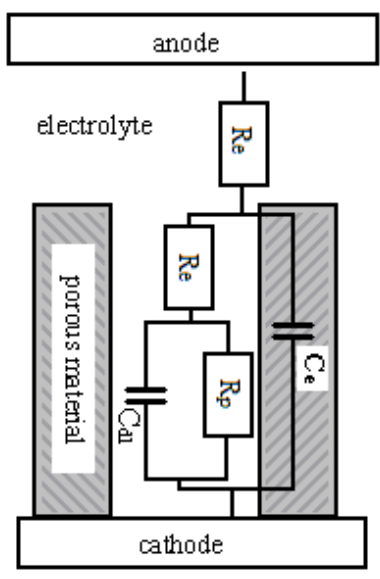

Fig. 13. The equivalent circuit of porous materials.

The double layer capacitor $C_{d l}$ and the resistance $R_{p}$ parallel connection describe the final part of the capillary in the equivalent circuit of porous materials. The resistance $R_{e}$ and the capacitor $C_{e}$ describe the hydrated surface of capillary (Fig. 13), while the resistance $R_{p l}$ and the capacitor $C$ of samples with particulate matter heated in $\mathrm{N}_{2}$ flow are in series (not in parallel connection) because of the glass fibres' material heterogeneity (Fig. 11, B).
The impedance modulus $|Z|_{(\omega)}$ of particulate matter was counted by the equations (1) and (2) accordingly, with fitted equivalent circuits shown in Figures 10, A and 10, B:

$$
\begin{aligned}
& |Z|_{(\omega)}=R_{1}+\frac{R_{2}}{1+R_{2} Q_{1}(j \omega)^{n}} \\
& |Z|_{(\omega)}=R_{1}+1 /\left(\frac{1}{R_{2}}+j \omega C_{1}+\frac{1+R_{3} Q_{1}(j \omega)^{n}}{R_{3}}\right)
\end{aligned}
$$

Where $R_{1}$ is electrolyte resistance, $R_{2}, R_{3}$ - polarization resistance, $Q_{l}$ - constant phase element, $n$ - phase-shift coefficient, $C_{l}$ - capacitor, $j=\sqrt{-1}$ - imaginary number, $\omega-$ radial frequency, which is equal $\omega=1 /(\mathrm{RQ})^{1 / \mathrm{n}}$.

Calculated values of impedance modulus $|Z|_{(\omega)}$ are shown in Tables 2 and 3. The obtained results of impedance modulus of impedance spectra at potential $-0.02 \mathrm{~V}$ were similar. Impedance values of particulate matter heated in $\mathrm{N}_{2}$ flow at potential $-0.02 \mathrm{~V}$ were higher than at potential $-0.1 \mathrm{~V}$. Impedance values of particulate matter heated in $\mathrm{O}_{2}$ flow at potential $-0.02 \mathrm{~V}$ were about 3-4 times higher than at potential $-0.1 \mathrm{~V}$.

Impedance modulus of particulate matter and impedance spectra obtained at potential in statistic area (at $-0.02 \mathrm{~V}$ ) are shown in Figure 14. Impedance modulus of particulate matter, impedance spectra obtained at potential in kinetic area (at -0.1 V) are shown in Figure 15.

TABLE 2

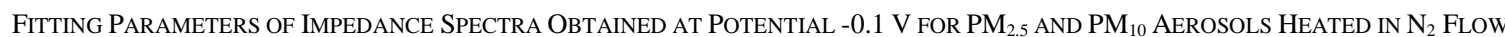

\begin{tabular}{|l|c|c|c|c|c|c|}
\hline & PM2.5-1 & PM2.5-2 & PM2.5-3 & PM10-1 & PM10-2 & PM10-3 \\
\hline $\mathrm{R}_{\mathrm{e}}, \Omega^{*} \mathrm{~cm}$ & 53.2 & 53.2 & 53.2 & 53.2 & 53.2 & 53.2 \\
\hline $\mathrm{R}_{\mathrm{p} 1}, \mathrm{~K} \Omega^{*} \mathrm{~cm}^{2}$ & $0.54 \pm 0.13$ & $4.14 \pm 0.12$ & $1.06 \pm 0.16$ & $0.46 \pm 0.03$ & $0.65 \pm 0.10$ & $0.70 \pm 0.08$ \\
\hline $\mathrm{C}_{1}, \mu \mathrm{F}^{*} \mathrm{~cm}^{-2}$ & $22 \pm 9$ & - & $17.8 \pm 1.4$ & $22 \pm 5$ & $16.2 \pm 1.3$ & $15 \pm 4$ \\
\hline $\mathrm{R}_{\mathrm{p} 2}, \mathrm{~K}^{*} \mathrm{~cm}^{2}$ & $3.1 \pm 1.2$ & - & $7 \pm 2$ & $3.3 \pm 0.2$ & $4.00 \pm 0.03$ & $2.9 \pm 0.3$ \\
\hline $\mathrm{Q}_{1}, \mu \mathrm{F}^{*} \mathrm{~cm}^{-2} \mathrm{~s}^{\mathrm{n}-1}$ & $156 \pm 25$ & $167 \pm 5$ & $188 \pm 12$ & $145 \pm 13$ & $132 \pm 13$ & $139 \pm 15$ \\
\hline $\mathrm{n}$ & 0.8270 & 0.7810 & 0.7882 & 0.8219 & 0.8230 & 0.8158 \\
\hline $\mathrm{q}, \mathrm{cm}^{2}$ & $0.48 \pm 0.04$ & $0.406 \pm 0.012$ & $0.44 \pm 0.01$ & $0.512 \pm 0.002$ & $0.542 \pm 0.005$ & $0.52 \pm 0.06$ \\
\hline$|\mathbf{Z}|_{(\omega)}, \mathbf{K} \boldsymbol{\Omega}$ & $\mathbf{1 . 4} \pm \mathbf{0 . 6}$ & $\mathbf{2 . 0 7} \pm \mathbf{0 . 0 3}$ & $\mathbf{3 . 4} \pm \mathbf{0 . 9}$ & $\mathbf{1 . 5 2} \pm \mathbf{0 . 1 2}$ & $\mathbf{1 . 8 7 4} \pm \mathbf{0 . 0 1 1}$ & $\mathbf{1 . 3 8} \pm \mathbf{0 . 1 5}$ \\
\hline
\end{tabular}

TABLE 3

\begin{tabular}{|c|c|c|c|c|c|c|}
\hline & PM2.5-1 & PM2.5-2 & PM2.5-3 & PM10-1 & PM10-2 & PM10-3 \\
\hline $\mathrm{R}_{\mathrm{e}}, \Omega^{*} \mathrm{~cm}$ & 53.2 & 53.2 & 53.2 & 53.2 & 53.2 & 53.2 \\
\hline $\mathrm{R}_{\mathrm{p} 1}, \mathrm{~K} \Omega * \mathrm{~cm}^{2}$ & $0.632 \pm 0.010$ & $0.282 \pm 0.008$ & $1.00 \pm 0.12$ & $2.3 \pm 0.9$ & $1.35 \pm 0.07$ & $0.72 \pm 0.07$ \\
\hline $\mathrm{C}_{1}, \mu \mathrm{F}^{*} \mathrm{~cm}^{-2}$ & $56 \pm 1$ & $99 \pm 12$ & - & - & - & $8.3 \pm 1.2$ \\
\hline $\mathrm{R}_{\mathrm{p} 2}, \mathrm{~K} \Omega * \mathrm{~cm}^{2}$ & $0.96 \pm 0.11$ & $1.1 \pm 0.7$ & - & - & - & $2.9 \pm 1.3$ \\
\hline $\mathrm{Q}_{1}, \mu \mathrm{F} * \mathrm{~cm}^{-2} \mathrm{~s}^{\mathrm{n}-1}$ & $446 \pm 48$ & $515 \pm 52$ & $726 \pm 48$ & $252 \pm 43$ & $512 \pm 43$ & $113 \pm 27$ \\
\hline $\mathrm{n}$ & 0.7509 & 0.7488 & 0.7650 & 0.7950 & 0.7243 & 0.8238 \\
\hline $\mathrm{q}, \mathrm{cm}^{2}$ & $0.25 \pm 0.02$ & $0.23 \pm 0.02$ & $0.117 \pm 0.002$ & $0.39 \pm 0.08$ & $0.24 \pm 0.02$ & $0.45 \pm 0.06$ \\
\hline$\left.|Z|_{(\omega)}\right), K \Omega$ & $0.44 \pm 0.05$ & $0.51 \pm 0.09$ & $0.50 \pm 0.06$ & $1.2 \pm 0.5$ & $0.68 \pm 0.03$ & $1.4 \pm 0.5$ \\
\hline
\end{tabular}

Fitting Parametrs of Impedance Spectra ObTaining at Potential-0.1 V for PM 2.5 And PM PM $_{10}$ Aerosols Heated in O $_{2}$ Flow 


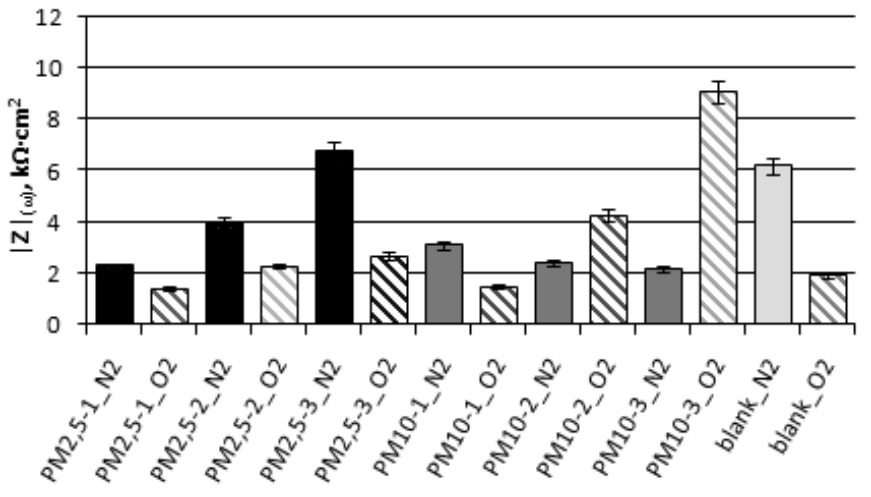

Fig. 14. Impedance modulus of heated $\mathrm{PM}_{2.5}$ and $\mathrm{PM}_{10}$ aerosols, impedance spectra obtained at potential $-0.02 \mathrm{~V}\left(\mathrm{~N}_{2}\right.$ - heated in nitrogen flow, $\mathrm{O}_{2}$ heated in oxygen flow)

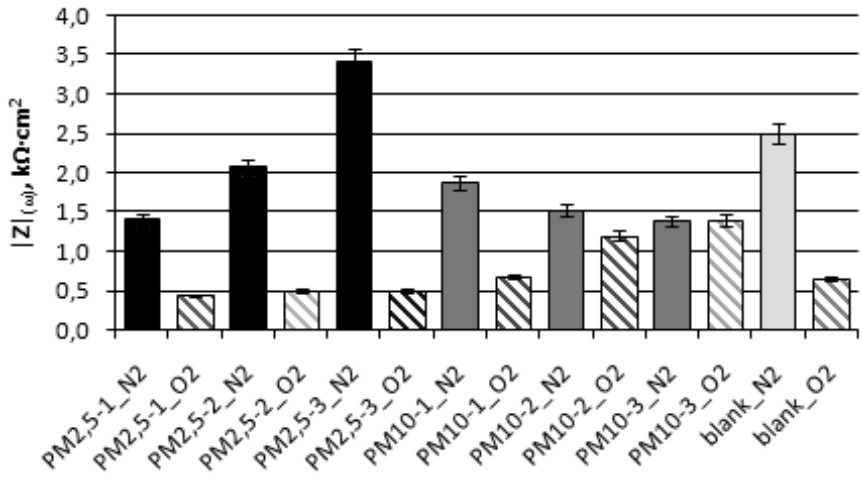

Fig. 15. Impedance modulus of heated $\mathrm{PM}_{2.5}$ and $\mathrm{PM}_{10}$ aerosols, impedance spectra obtained at potential $-0.1 \mathrm{~V}\left(\mathrm{~N}_{2}-\right.$ heated in nitrogen flow, $\mathrm{O}_{2}-$ heated in oxygen flow).

Impedance modulus of particular matter were higher, if impedance spectra were obtained at potential in the statistical area $(-0.02 \mathrm{~V})$, rather than at potential in the kinetic area $(-0.1$ $\mathrm{V})$. Comparing values of modulus depending on the kind of treatment, the impact of heating kind to the sample's impedance was observed: mainly the impedance of particulate matter heated in $\mathrm{N}_{2}$ flow was higher (Fig. 14 and 15). It can be described with a carbon presence in the samples heated in $\mathrm{N}_{2}$ flow. Black carbon blocked filters' pores, changing characteristics of its surface.

The statistical method was used to compare the obtained data of impedance spectra. The statistical method is based on the check equality of impedance spectra by Student's t-test [12], using MS Excel panel of the data analysis t-Test: TwoSample Assuming Unequal Variances. It was assumed that data sets of impedance spectra came from distributions with unequal variances, because the samples had many differences (particles' size and pre-treatment variations, weather conditions were not stable at particular matter sampling time, etc.). Two criterions were checking to compare impedance spectra. The first, criterion $P(T<=t)$ two-tail value should be larger than significance level $\alpha$. Usually significance level $\alpha$ value is 0.05 , that means probability of condition error is $<5 \%$.
The second, $t$ Critical two-tail value should be large than $t$ Statistic value. If both criterions were fulfilled, the compared impedance spectra did not have a considerable difference, so they varied in a random error limit. Thus, by checking the impedance spectra of particulate matter, it was concluded that impedance augments are insignificant for the increasing mass concentration of $\mathrm{PM}_{2.5}$ aerosols heated in $\mathrm{N}_{2}$ flow (Fig. 15 and 9) and their impedance spectra varied in a random error limit. Nevertheless augments of impedance values were significant for increasing mass concentration of $\mathrm{PM}_{10}$ aerosols heated in $\mathrm{O}_{2}$ flow.

\section{B. Double Layer Capacitance Evaluation}

The dependence between analyzing samples' modulus of double layer capacitance $|C s|$ and potential is shown in Figures 16 and 17.

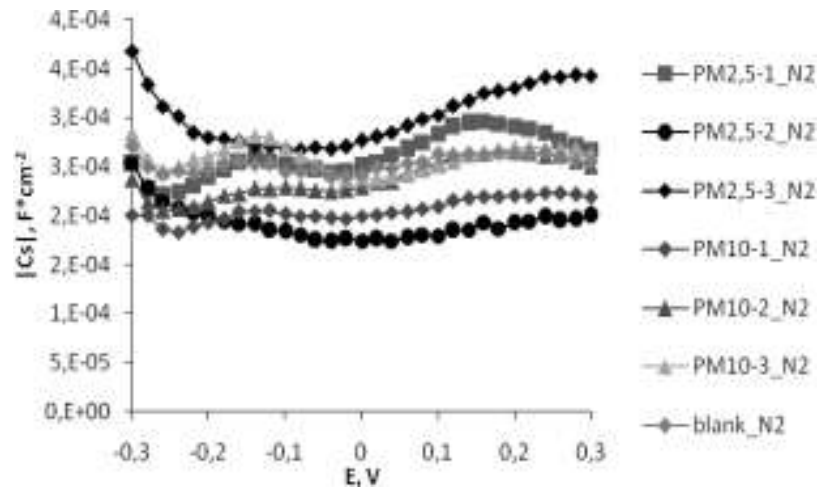

Fig. 16. Dependence between double layer capacitance and potential of $\mathrm{PM}_{2.5}$ and $\mathrm{PM}_{10}$ aerosols heated in nitrogen flow.

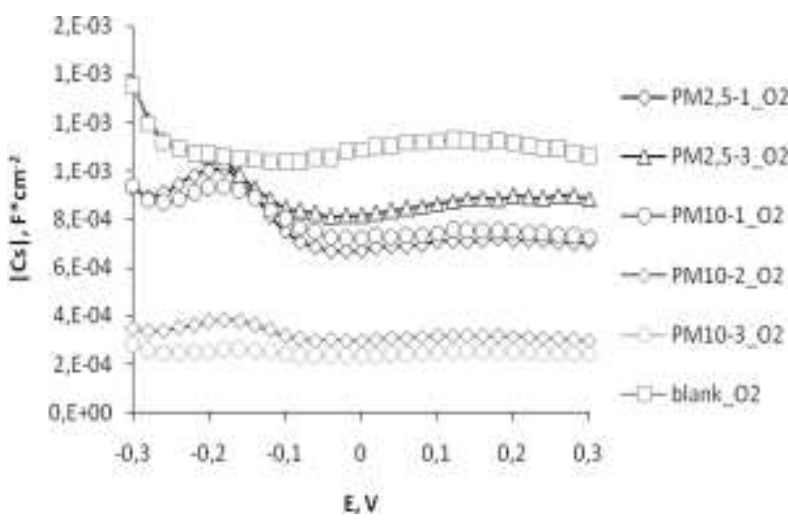

Fig. 17. Dependence between double layer capacitance and potential of $\mathrm{PM}_{2.5}$ and $\mathrm{PM}_{10}$ aerosols heated in oxygen flow.

In Figures 16 and 17, double layer capacitances of particulate matter were compared, depending on the kind of pre-treatment. The difference between the double layer capacitances of coarse and fine particles heated in $\mathrm{N}_{2}$ flow was insignificant, as shown in Figure 16. Nevertheless, the difference was between the samples heated in $\mathrm{O}_{2}$ flow (Fig. 17): by increasing mass concentration of coarse aerosols, the double layer capacitance reduced. 
The double layer capacitances of particulate matter heated in $\mathrm{N}_{2}$ flow were less than particulate matter heated in $\mathrm{O}_{2}$ flow, as shown in Figure 18. There were no differences between double layer capacitances of particulate matter heated in $\mathrm{N}_{2}$ flow with particles' size variation, but the double layer capacitances of particulate matter heated in $\mathrm{O}_{2}$ flow with particles' size variation was various. From this, it was concluded that the black carbon layer in samples heated in $\mathrm{N}_{2}$ flow had the same double layer capacitance $\left(192-302 \mu \mathrm{F} \cdot \mathrm{cm}^{-}\right.$ ${ }^{2}$ ), despite the mass concentration of the particular matter variation. Whereas other particular matter components differently influenced the double layer capacitance: the double layer capacitance of fine particles was not changed (because its double layer capacitance had very little difference from the capacitance of blank sample - filter without particular matter), the double layer capacitance of coarse particles was significantly increased, in addition, by increasing mass concentration of $\mathrm{PM}_{10}$ aerosols, the double layer capacitance reduced most.

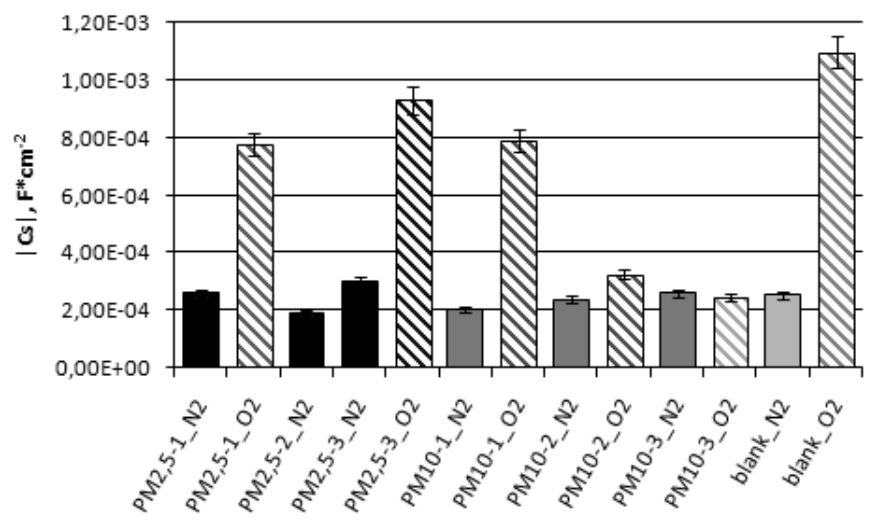

Fig. 18. Double layer capacitance of $\mathrm{PM}_{2.5}$ and $\mathrm{PM}_{10}$ aerosols $\left(\mathrm{N}_{2}-\right.$ heated in nitrogen flow, $\mathrm{O}_{2}-$ heated in oxygen flow).

\section{CONCLUSIONS}

- Sampling particulate matter equal number of hours, mass concentrations of $\mathrm{PM}_{2.5}$ aerosols were in the range from 5 to $24 \mu \mathrm{g} / \mathrm{m}^{3}$ and of $\mathrm{PM}_{10}$ aerosols - from 3 to $10 \mu \mathrm{g} / \mathrm{m}^{3}$. Hence, the number of fine aerosols is much higher in ambient atmosphere, although coarse particles are heavier than fine particles.

- Heating in $\mathrm{O}_{2}$ flow and carbonisation in $\mathrm{N}_{2}$ flow helped to increase the sample's wetting in electrolyte that contributed to obtaining the qualitative impedance spectra.

- Potentials for impedance spectra measurements can be defined from cyclic voltammograms, to describe processes of the system in statistic and kinetic areas. Particular matter's impedance spectra measurement in the statistic area should be obtained at the potential of $-0.02 \mathrm{~V}$, but in the kinetic area - at the potential of $-0.1 \mathrm{~V}$.

- Describing the impedance spectra, it was observed that particular matter heated in $\mathrm{N}_{2}$ flow had the same characteristics of surface, independently from mass concentration and size variations. In turn, other components, which were not black carbon, changed characteristics of the surface already at $\mathrm{PM}_{10}$ mass concentration (3.24 \pm 0.05$)$ $\mu \mathrm{g} / \mathrm{m}^{3}$, but they did not change characteristics of surface even at $\mathrm{PM}_{2.5}$ mass concentration $(24.0 \pm 0.2) \mu \mathrm{g} / \mathrm{m}^{3}$.

- Describing the impedance spectra, the heterogeneous, without certain size of pores, rhomboid or triangular structure of glass fibre filter was observed.

- Describing the spectra of the double layer capacitance, it was observed that mass concentration and size variations did not impact the values of the double layer capacitance of black carbon. But by increasing mass concentration of coarse aerosols heated in $\mathrm{O}_{2}$ flow, the double layer capacitance reduced.

\section{REFERENCES}

1. Veselības inspekcija. Āra gaiss. Rīga: LR VM Veselības inspekcija, 31.05.2011. [atsauce 16.06.2011]. Piejams: http://www.vi.gov.lv/lv/vides-veseliba/gaiss/ara-gaiss

2. Smith D.M., Chughai A.R. The Surface Structure and Reactivity of Black Carbon. Colloids and Surfaces, 1995, A105, p. 47-77.

3. Ramanathan V., Carmichael G. Global and Regional climate changes due to black carbon. Nature Geoscience 1, 2008, p. 221-227.

4. Carchier H. Carbonaceous Combustion Aerosols. In IUPAC Series on Analytical and Physical Chemistry of Environmental Systems, V. 5, in Atmospheric Particles. Ed. by Harrison R.M., Van Grieken R.E. Wiley J., Chichester, 1998, p. 295-348.

5. Seinfeld J.H., Pandis S.N. Particulate Matter (Aerosols) in Atmospheric Chemistry and Physics: from Air Pollution to Climate Change. Ed. by Willey J., New York, 1998, p. 97-108.

6. Ruzer Lev S., Harley N. H. Aerosol's handbook: measurement, dosimetry, and health effects. USA: CRC Press, 2005, p. 27.

7. Mounk P. Fundamentals of electroanalytical chemistry. UK: John Willey \& Sons LTD, 2001. p. 253-264.

8. Osite A., Katkevich J., Viksna A., Vaivars G. Electrochemical Impedance Spectra of Particulate Matter and Smoke. Material Science and Engineering, 23, 2011, 5.

9. Bard A J., Faulker L.R. Electrochemical methods: fundamentals and applications. $2^{\text {nd }}$ ed. USA: John Willey \& Sons, 2001, p. 226-228.

10. Basics of Electrochemical Impedance Spectroscopy. USA: Application note, Gamry instruments, 2008, p. 30.

11. Orazem M.E., Tribollet B. Electrochemical impedance spectroscopy. Canada: John Wiley \& Sons, Inc., 2008, p. 353-355, 158-159, 49-55.

12. Lasia A. Electrochemical Impedance Spectroscopy and Its Applications, Modern Aspects of Electrochemistry. Ed. by E. Conway, J. Bockris, R. E. White, Vol. 32, p. 143-248,. Kluwer Academic/Plenium Publishers, New York, 1999, p. 49.

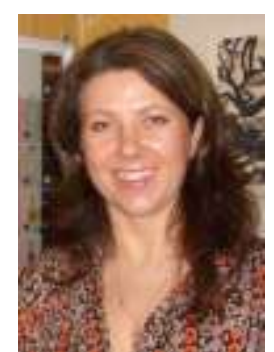

Agnese Osite, Dr.Chem., Professor Assistant at the University of Latvia

Faculty of Chemistry, Department of Analytical Chemistry. A. Osite obtained her scientific degree in chemistry at the University of Latvia in 2008 and the topic of the doctoral thesis was about improvement of analytical measuring cycle methodology in analyses of particulate matter, surface waters and pine needles. The scientific studies are devoted manly to one of the most important environmental polluter - ambient particulate matter and their chemical analysis.

Address: University of Latvia, Faculty of Chemistry, Kr. Valdemara Str. 48, Riga, LV 1013, Latvia

E-mail: agnese.osite@lu.lv

Margarita Baitimirova, BSc. First year master student of University of Latvia, Faculty of Chemistry. M. Baitimirova obtained her BSc. in chemistry at the Faculty of Chemistry in 2011.

Address: University of Latvia, Faculty of Chemistry, Kr. Valdemara Str. 48, Riga, LV 1013, Latvia

E-mail: mb08101@lu.1v 
Juris Katkevics, Dr.Chem., Leading researcher at the University of Latvia, Faculty of Chemistry, Department of Analytical Chemistry. J. Katkevics obtained his scientific degree in chemistry in 1992. J. Katkevics is author of more than 130 scientific papers and several patents. Now research interests of J. Katkevics are related to studies of nano - materials, pharmaceutical and archaeological materials, application of new analytical methods and different model experiments.

Address: University of Latvia, Faculty of Chemistry, Kr. Valdemara Str. 48, Riga, LV 1013, Latvia

E-mail: katju@lanet.lv

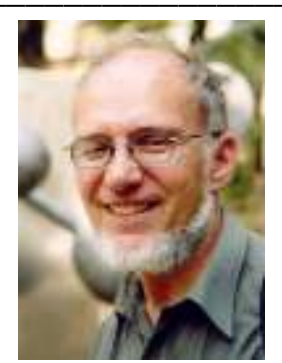

Arturs Viksna, Dr. Chem., Professor at the University of Latvia, Faculty of Chemistry, Department of Analytical Chemistry. A. Viksna obtained his scientific degree in analytical chemistry of ion selective electrodes at University of Latvia in 1993, but licentiate degree in Environmental Sciences at Chalmers University of Technology and University of Gothenburg (Sweden) in 1996. Now he is vice-dean of Faculty of Chemistry and chair of Analytical Chemistry of University of Latvia. He is also a member of Virtual Institute of Reference materials (VIRM) and research interests are related to development and application of new analytical methods to environmental pollution, archaeology, solar silicon and new material (including nano-) studies. Address: University of Latvia, Kr. Valdemara 48, LV-1113, Riga, Latvia E-mail: arturs.viksna@lu.lv

Margarita Baitimirova, Agnese Osīte, Juris Katkevičs, Arturs Vīksna. Gaisa aerosolu daḷinuu elektroḳīmiskie raksturojumi

Pêtījumā veikta elektroḳīmiskās impedances un dubultslāṇa kapacitātes spektru analīze Rīgas pilsētvides gaisa smalkajām un rupjajām aerosolu daḷiņām, kas uzkrātas uz stikla šķiedras filtriem. Veicot frakcionēto aerosolu daḷiņu ņemšanu vienādu stundu skaitu, smalko daļinu daudzums bija krietni augstāks par rupjo dalịnu daudzumu gaisā. Pēc aerosolu daḷiņu paraugu karsēšanas dažādas vidēs tika uzṇemtas cikliskās voltamperogrammas, impedances spektri un dubultslānna kapacitātes spektri. Kvalitatīvu impedances spektru uzṇemšanai izmantoja „sviestmaizes” veida elektroḳīmisku šūnu. Pēc uzṇemtām voltamperogrammām tika noteikti nepieciešamie parametri aerosolu dạiṇu paraugu impedances mērījumiem. Impedances spektru analīzei izmantota ekvivalento shēmu metode un statistiskā metode. Mērījumu precizitāte un ticamība pirms analīzes pārbaudīta ar Krāmera-Kroniga testu. Analizējot impedances spektrus, tika konstatēts, ka gan smalkajām, gan rupjajām, slāpekḷa vidē karsētām aerosolu dalininām impedance nemainās, mainoties daḷinuu masas koncentrācijai. Savukārt, gaisā karsētiem paraugiem impedance pieaug, pieaugot rupjo dạ̣iņu masas koncentrācijai. Analizējot dubultslānna kapacitātes spektrus tika novērots, ka dubultslāņa kapacitāte slāpekḷa plūsmā karsētām aerosolu daḷin̄ām nemainās, mainoties dạıiṇu izmēram un masas koncentrācijai, bet pieaugot skābekḷa plūsmā karsēto, rupjo aerosolu dalinnu masas koncentrācijai, dubultslāņa kapacitāte samazinās. Kopumā iegūtie dati liecina par ogles, galvenā aerosolu dalinu komponenta, virsmas rakstura nemain̄̄gumu, mainoties aerosolu dạ̣iņu izmēram un masas koncentrācijai. Analizējot impedances spektrus augsto frekvenču apgabalā tika noteikta nehomogēna, bez noteikta poru izmēra, trīsstūrveida vai rombveida stikla šķiedru filtra uzbūve.

Маргарита Байтимирова, Агнесе Осите, Юрис Каткевичс, Артурс Виксна. Электрохимические характеристики аэрозольных частиц возду ха Данное исследование посвящено анализу спектров электрохимического импеданса и емкости двойного слоя собранных на фильтрах из стекловолокна мелких и крупных аэрозольных частиц воздуха Рижской городской среды. Собирая фракции аэрозольных частиц одинаковую продолжительность времени, количество мелких частиц было гораздо выше количества крупных частиц в воздухе. После прогрева образцов в разных средах были сняты циклические вольтамперограммы, спектры импеданса и спектры емкости двойного слоя. Для получения качественных спектров использована электрохимическая ячейка „бутербродного” типа. По полученным вольтамперограммам определены необходимые параметры для измерений импеданса образцов аэрозольных частиц. Спектры импеданса проанализированы методом эквивалентных схем и статистическим методом. Перед анализом точность и правдоподобность измерений проверены тестом Крамера-Кронига. Измеряя электрохимический импеданс аэрозольных частиц, абсорбированных на поверхности фильтра из стекловолокна, с изменением массовой концентрации частиц констатирована неизменность импеданса и у мелких, и у крупных аэрозольных частиц, прогретых в среде азота. В свою очередь, импеданс образцов, прогретых на воздухе, увеличивается при повышении массовой концентрации крупных частиц. Анализируя спектры емкости двойного слоя, замечено, что емкость двойного слоя аэрозольных частиц, прогретых в среде азота, не меняется при изменении размера частиц и массовой концентрации, но с увеличением прогретых в среде кислорода крупных аэрозольных частиц емкость двойного слоя уменьшается. В общей сложности полученные данные свидетельствуют о неизменности характеристики поверхности угля, главного компонента аэрозольных частиц, при изменении размера и массовой концентрации аэрозольных частиц. Анализируя спектры импеданса в области высоких частот, констатировано неоднородное, без определенного размера пор, треугольное или ромбовидное строение фильтра из стекловолокна. 